\title{
Anthropological Perspective Study on the Muslims in Mysore City-India (Case study Shia Muslims)
}

\author{
Jalal Jafarpour ${ }^{1}$ \\ ${ }^{1}$ Department of Social Sciences (Anthropology), University Lecturer, Islamic Azad University, Lahijan, Iran \\ Correspondence: Jalal Jafarpour, Department of Social Sciences (Anthropology), University Lecturer, Islamic \\ Azad University, Lahijan, Iran. Tel: 98-912-708-1902. E-mail: jfpour@gmail.com
}

Received: July 20, 2016

Accepted: August 2, $2016 \quad$ Online Published: November 16, 2016

doi:10.5539/res.v8n4p137

URL: http://dx.doi.org/10.5539/res.v8n4p137

\begin{abstract}
India, because of including a collection of religions and religious minorities altogether in itself, especially in this modern era, is a remarkable case of study and consideration. This study also, as an anthropological research and in order to get familiar with the religious identity of Muslims and Shias of Mysore in particular, has played its role. This project is a case study about the Shia Muslims in Mysore; it has also a historical look upon formation of cultural identity of Shias in India. During the reign of the Arab traders, they brought Islam into the South Indian state of Karnataka almost as soon as the faith was initiated in Arabia. Along with their faith, Muslims brought many products to the region. The Islamic presence and power in the state reached its greatest heights during the reigns of Hyder Ali and his son Tippu Sultan. Though killed by the British in 1799, Tippu Sultan was one of the only national leaders to defeat the British in battle and is still considered a hero for many Indians. The internal structure of Indian Muslims as a religio-ethnic group was quite complex. Shias Islam has deep-rooted influence in present and history of India from North to South with various Shia Muslim dynasties ruling Indian provinces from time to time.
\end{abstract}

Keywords: Muslims in Mysore, anthropological study, Shia, Muslim community of India

\section{Introduction}

Islam means submission. Those who submit are called Muslims. There are five pillars for all Muslims to adhere worldwide: 1) there is no God but Allah, and Mohammad is his prophet. 2) Praying five times daily, kneeling in the direction of Mecca (the holy city). 3) Giving of alms (a share of each Muslim's income is given to support the mosque and the poor). 4) Fasting throughout Social-Intellectual (the ninth month of the Muslim calendar). 5) Visiting the Hajj (every believer who is able to do so must go on a pilgrimage to Mecca). Islam teaches absolute monotheism and Mohammed's primacy as Allah's last Prophet on earth. Islam stresses the brotherhood of believers, no difference of religion and secular life, obedience to God's Law, abstinence from alcohol, and of good works. Shab-e-Barat, Id-Ul-Fitr, Id-Ul-Zuha, Muharram and various Ures of Sufi saints are the major festivals observed by them. The religion of the Muslims is the youngest of the great religions in the world. The process of Islam is becoming a more prominent part of the political and social order. This may be through adoption of laws based on Islam a stricter code of behavior for Muslims in a community, or significant portions of a population converting to Islam (Madan, 2007). India is a diverse mix of different religions and religious sects, most of them are derived from Hindu, Islam and Buddhism. About $82 \%$ of the people of India are following Hindu rituals and about $13.4 \%$ are Muslims. India also has more than $2.3 \%$ Christians and $1.9 \%$ Sikhs. Although India was the birthplace of Buddhism, the Buddhist population in India is currently estimated at only about $0.8 \%$. In addition, Jainism, $0.8 \%$ followers of Zoroastrianism, Jewish, Baha'i and other faiths is 30 Afro Asian Journal of $0.4 \%$. However, India's largest community of Iranian Baha'i and Zoroastrian religious sect, Ahmadieh are around the world. Most of the Muslims in Delhi, West Bengal and northwest areas of the population have been living in Kashmir. Thus, India has the largest Muslim population after Indonesia and Pakistan in the world (Ahmad \& Imitiaz, 1981). India is one of those countries in which Islam has brought development and flourished of civilization. History of Islam's introduction to India starts from the end of 1st century Hegira, i.e., the 7th century AD with the decline of Sasanid Dynasty. Spread of Islam in the time of Mahmud Qaznavi and his conquests in Punjab continued and reached its climax in the time of Gurkanis to 1526 $\mathrm{AD}$, since 932 Hegira equal, all government and religious positions were in the hands of Iranians (Mutahhari, 
1983). Qutub Shahis made efforts for preaching Islam and Shiism in Deccan. Once upon a time, Shias of India had governmental power and had undeniable penetration in the government systems. At the moment, study of Shias has become an important subject for research in the Subcontinent, and there are so many scientific and research-related valuable works at hand, like the books Shia and Shia Islam in India, John (1946) and a socio-Intellectual History of the Isna Ashari Shiis in India, Saiyid (1988) in which very good studies are done about Shias and historical, political-social and cultural problems are discussed in it. At the moment, the population of Muslims in India reaches over 200 million and they are scattered in different regions of this country. This study, however, concentrates on the Mysore city on Shias; the center of this religious minority in this region is Deccan which has always welcomed Iranian culture and Shiism from long ago and is the root of Shias development in India. "Deccan" was the name given to the southern parts of the Indian subcontinent in the past. The State of Karnataka and the city of Mysore are located in this region as well. Although historically Shiism has its origins in Arab nations, it rapidly and widely grew in Iran, Pakistan and India. This paper explores, by discussing ethnographic examples from different parts of Mysore and beyond, the multi-dimensional and many-layered contexts of reciprocally shared cultural realms and inter-religious and synthesized cultural formations, including common religious observances.

Questions of research:

How were the main bases of Shias and their geographical position in Southern India and in Mysore? Who had the most influence in spreading the Shias culture in Southern India and Mysore? The migration of Shias in Southern India and Mysore?

\section{Research History}

The anthropological approach to the study of religion involves the scientific and not the humanistic concept of culture. The basic feature of the scientific approach to the study of religion are four-fold; universality, empiricism, comparison, and objectivity. Universality: it implies that the anthropological approach encompasses all known religions and religious phenomena and that it does not exclude any on the basis of "taste", "decency", or similar unscientific considerations. Ethical and moral standards differ from culture to culture, and it is the scientific task of the anthropologist to study them as they actually exist, and make sense out of them with reference to the context (Dale \& Stephen, 1988).

Empiricism: The study of religion in contemporary anthropology is empirical because it is family rooted infield research. The main body of data used for analysis is gathered by anthropologists through direct contact with the carriers of the various cultural traditions. Not only is this method more reliable than the one dependent upon reports from untrained observers, but it also affords the field worker an opportunity to examine religion in the total cultural context. Comparison: Through the systematic comparison of similar religious phenomena, anthropologists seek to achieve a greater or lesser amount of generalization. These comparisons may also reveal historical relationships and evolutionary sequences or many serve as a basis of typology building. Objectivity: The anthropological study of religion demands that the investigator remain impartial and unbiased (Irfan, 2008).

As an anthropologist, he is not concerned with the possible truth or falsehood of particular religious beliefs as such but with their existence and the significance, which the people attach to these beliefs, rituals, etc. These four principles, combined with the holistic approach and the application of the concept of culture, constitute the basis of anthropological methodology. Anthropologists use the basic field work method not only in their studies of specific groups of people, but also in many instances where they turn their attention to one specific phenomenon, be it language, kinship, social organization or religion. An anthropological study of religion will thus give an insight not only into the nature of religion itself, but into many other cultural institutions and human behavior (Hefner \& Robert, 1998).

Cultural Diversity, religious Syncretism and People of India (Mysore) and an anthropological Interpretation Abstract Ethnic origins, religions, and languages are the major sources of cultural diversity. India is a country incredible for its biological and cultural diversity. However, the process of synthesis and integration has been extensively at work in most parts of India. Indeed ethnic identities and even the culture traits of Indian people have never been frozen in time or in space, they have been in a state of flux. Though each group or community has a distinctive identity and ethos of its own, it does not exist in a social vacuum (Roma, 1998).

Rather, it forms part of an extended and dynamic network. The sharing of space, regional ethos and cultural traits cut across ethnic and sectarian differences and bind the people together. Thus, we witness a firm balancing between cultural diversity and syncretism pervading the foundation of Indian civilization. Indeed by extension, such cultural phenomena are observable, to lesser or greater degree, in the entire sub continental civilizational arena. The pre-existing sub continental civilizational continuum historically includes and encompasses ethnic 
diversity and admixture, linguistic heterogeneity as well as fusion, and synthesis in customs, behavioral patterns, beliefs and rituals. In the present era of growing cultural condensation, syncretism-synthesis is fast emerging as a prevailing event (Gadgil \& Guha, 1992).

India is a country incredible for its biological and cultural diversity. It is the natural resources that attracted many streams of people to the subcontinent at different times, from different directions; bringing together a great diversity of human genes and human cultures (El Zeinh, 1977). The spiritual notion of equality in Islam ceased to have political and economic reality. The Muslim tradition in India was dominated by the prevailing social system: the presence of hierarchy and class consciousness, superstitious and consciousness of rights. The Muslims were deeply religious but Islam had departed from the Arabian type. As most of the Muslims were converts from the Hindu fold, they shared with the Hindus the same passion and love for the soil. They had many things in common with the Hindus (Hefner, 1998). Prof. Mujeeb also writes, "the structure of the Indian Muslim society has little resemblance to the democratic classless community integrated and inspired by the belief in One God, which the Indian Muslim fondly imagines it to have been a very complex organism, containing within itself healthy and unhealthy tensions, and forces of growth, stability and decay" (Ahmad \& Imitiaz, 1973).

There are many books written about Muslim rule in India, which provide the details of different dynasties.

Here, we are more concerned with the synthesis that took place between the rulers and the rules during that period. Singhal writes in detail about the influence of Islam on Indian society and vice versa. He writes that the impact of Muslim rule was greater on urban life than rural. Influenced by the royal court, the urban population attained a high degree of sophistication in language and literature, art and crafts, manners, dress, diet, luxuries and refinement. In the Indian villages where practically the entire Muslim population was descended from Hindu converts, the traditional Hindu outlook and social forms were retained (Osella \& Caroline, 2007).

The Muslim communities are linguistically heterogeneous; in all, many languages are spoken by them in different states. The Urdu language is spoken by the largest number of communities; followed by Kashmir, Kutchie, Gujarati, Marwari, Hindi, Bengali, Malayalam and Hariyanvi. Other languages spoken are Arabic, Assamese, Awadhi, Marathi, Mewari, Sindhi and Tamil. They all speak regional dialects as well. Muslims in North India are generally organized around biradaris (the term is used in various ways, as jati, qaum or qwabila and also Khandan or Kumba), which are placed in a hierarchical order. The biradaris among the lower order of the Muslim social hierarchy generally maintain the norms of endogamy. Under the impact of Islamisation, there have been changes in the names of the lower orders: the Qasai are now Qureshi or Sheikh Qureshi; the Lohar call themselves Saifi; the Julaha prefer the term Ansari or Momin Ansari. Muslim identity has been reinforced by the collective observance of festivals like Id. The Muslim is primarily a rural population $(65.99 \%)$, with a substantial number of them living in urban areas (34.01\%), which is higher than the national level (Filppo \& Caroline Osella, 2008).

The Sunni Muslim inhabits all the districts of the state. They speak Urdu within the family and kin groups and Kannada with others. They use the Perso-Arabic script among themselves as well as with others. They are non-vegetarians who take chicken, mutton and beef. Rice, wheat and ragi are their staple cereals. Consanguineous marriage with one's father's brother's daughter or mother's sister's daughter is permitted and sororate (junior) is allowed. Adult marriages are settled through negotiation and monogamy is the common form.

Polygyny though allowed is rarely practiced. A Lachcha is the symbol of marriage for women. Dowry or meher is fixed for the girl and is promised for future payment while dowry is paid in both cash and kind, they follow the partly local rule of residence after marriage. Divorce is permissible with religious sanction and both men and women can seek it. Remarriage of widows, widowers and male and female divorcees are permissible. Of late, marriageable age among them has reportedly increased. They generally prefer to live in nuclear families. All children get a share from their father's property, but females inherit less than the males. Women have a role to perform in bringing potable water, social functions, ritual and religious spheres. They observe pre-delivery ritual (satvase) during the seventh month of pregnancy. The child is named on the day of birth. They observe pollution for 40 days after the delivery and a purification ceremony, chill, is performed. Aqiqa and initiation (maktab) ceremonies are performed for both male and female children while circumcision is performed for boys between 5 and 7 years of age. The puberty rites are observed for girls. The marriage rituals are performed at the bride's residence and a feast is hosted by the bride's parents. The nuptial ceremony is performed at the groom's residence. Nikah is the most important marriage ceremony held at the residence of the bride, in which the Imam conducts the proceedings. The consent of the bridegroom to accept the bride as his life partner is taken at that ritual. The dead are buried. A death rite known as ziarat is observed on the third day and chelam on the fortieth 
day after a death (Mines \& Mattison, 1975). Trade, industry, transport and business are their main occupations. A few of them are employed in government and private services. They have an association, the Sunnatual Jamat, which looks after the welfare of the community. They profess Islam and their sacred specialist or imam is from the same community who officiates during all life-cycle rituals, besides performing worships and imparting religious teachings. Ramadan, Bakrid, Muharram and Meelad are their festivals which are of religious significance. Traditionally the Sunni Muslims exchange water and cooked food with other Muslim subgroups. They also exchange food with the Christians and share water sources with other communities. The burial ground is shared with other Muslim subgroups. They participate in festivals like Muharram and Id. Formal education is favored for their boys and partly favored for girls. Their attitude towards modern medicines is favorable and they make full use of modern healthcare facilities. Family welfare programmers also find favorable response from them. They are covered under the IRDP. Some of them are self-employed as auto-rickshaw drivers and general merchants. Rations are available to them through fair-price shops (Mayaram Shail, 1998).

\subsection{Karnataka}

Mysore is one of the important districts in Karnataka state and is situated in the Deccan Peninsular. According to 2001 census, the population of Karnataka was 52.73 million. The population of Karnataka has increased to $17.20 \%$ as compared to the last census. The state of Karnataka is ranked ninth in terms of population in India. Karnataka is one of the top states in terms of literacy rate in India. According to the census of 2001, Mysore city had a total population of 799,228 and among this population, 19\% were Muslims. Although most Muslims in Mysore were Urdu speaking, but Mysore has several other Muslim communities (ElZeinh \& Abdul Hamid, 1977).

Arab traders brought Islam into the South Indian state of Karnataka almost as soon as the faith was initiated in Arabia. Along with their faith, Muslims brought many products to the region. Muslims introduced coffee, incense sticks and the paper industry to the local economy. According to 2011 Census, the population of Karnataka has $31,057,742$ males 30,072,962 females the sex ratio in Karnataka is 1000 males for every 968 females. The total population of Hindus was $-83 \%$ the Muslims $-11 \%$ the Christians $-4 \%$, Jains $-0.78 \%$ and Buddhist $-0.73 \%$ (Ahmad \& Imitiaz, 1981).

\subsection{Muslims in Mysore}

About 500 years old Mysore city came into existence before the period of Hyder Ali and Tipu Sultan during the period of Raja Chak Dev Raj Wandeyar. From 1673 till 1704 Wadeyar Kings ruled in Mysore for a longtime and they had alliance with Aurangzeb and the Emperor accepted them as his governors. Aurangzeb gave Chikka Deva Raja Wandeyar five symbols of governments: Flag, Neshan-i-Mahi, Naqara, Khilatht, Takhtvataj. In addition to these, Aurangzeb gave one official Persian seal to Wandeyar and kings used this as government monogram during the entire period of Wandeyar dynasty. On the official seal, it was written in Persian "Ahmand Shahi with date 1162 Hijri". However, the migration of Muslims started during the period of Hyder Ali and Tipu Sultan, and in that period majority of Muslims was living in Mysore.

\section{Methodology}

This research project is mainly qualitative research. The present work aims to study Muslim Shia's in India. The main data collection methods would be case studies, and books.

Standard Anthropological techniques such as observation, interviews, case study, genealogy, participant observation method the rites, rituals, life cycle rituals, fairs and festivals and religious practices will be collected in different sacred complexes secondary information will be collected from the library, community associations, department of statistics, department of social welfare and social welfare offices, minority cells established in different places. Earlier studies on the Muslim and other related materials are collected among the religious leaders.

\section{Findings}

Mr. Sadat aged 40; there are 26 Ashorakhanas in Mysore out of which 23 are managed by donations of people and 3 more belong to the Association of Jafari Mosque in Mysore: Husseinia Association, Bab-ul-Havaej and Jelvezar Husseini which are supported by Jafaria Mosque. 


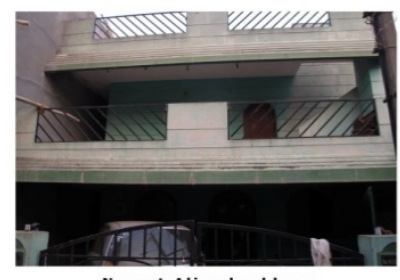

Nosrat Ali ashorkhana

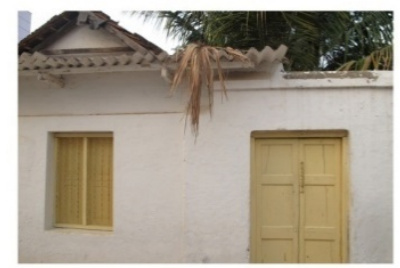

Nawaghar ashorkhana

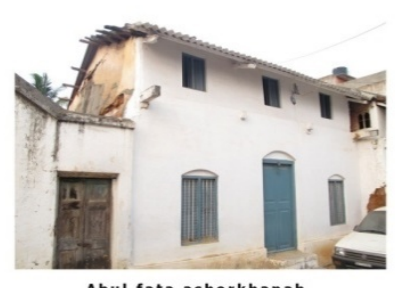

Abul fata ashorkhanah

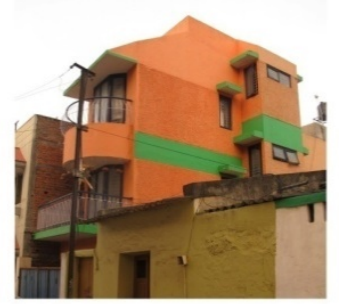

Niazmand Ali ashorkhana

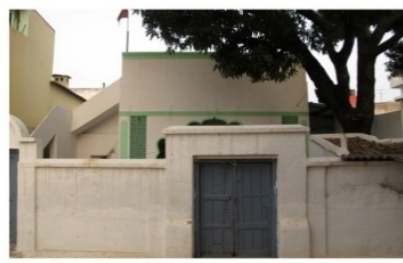

Sajadiya ashorkhana

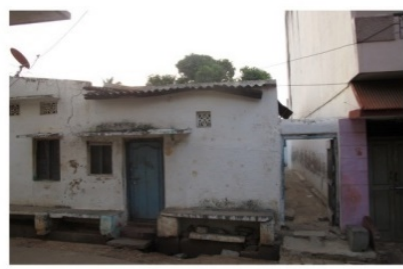

jani bhai ashorkhna

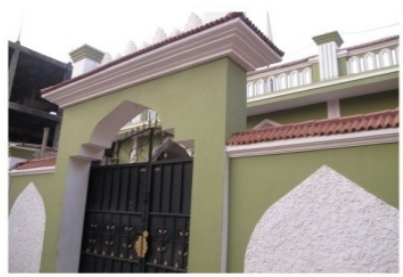

Seventh of moharam ashorkhana

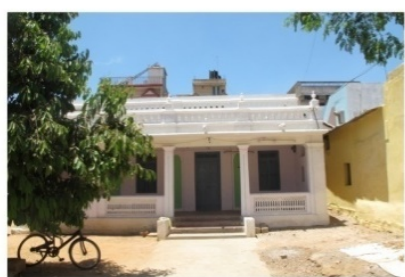

jelve zarila ashorkhana

Figure 1. Sometimes Ashorakhana in Mysore

Ashorakhanas at the homes of people: Ali Hussein, Askari Imam Bara, Fayazi, Ghazali and Mir Gholam Hussein, Mirza Ghanbar Ali in (Lashkar Mohalla).

Hassan Niafi, Mir Maghbol Hussein, Mir Moheb Hussein, Arman Leila Khanom, Azakhana Zeinabia, Azakhana (Shamim) Taher Ali, Azakhana Nosrat, Azakhana Rashke Behesht, Azakhana Alijan, Azakhana Chachi, Niazmand Ali, Mirza Taher Ali, Mir Abul-Fattah, Mir Mottaghi Ali (in Mandi Mohalla) Mir Nasir Ali, Mir Naser Ali, Mirza Karam Ali, Mir Hashem Ali, Mir Sajed Hussein (in Udaygiri) Khoja Yusuf Ali, Mirza Ehsan Ali (Bani Mantab) Some of the Shias rituals in Mysore: Moharram is very much considered in Mysore, the eating customs, clothing customs, etc. Usually in Moharram, people wear white or black clothes; generally, white and black colors are more popular. These clothes are blank and without any patterns. About the type of food, we have to say that in the first 10 days of Moharram, they try not to eat meat, some of them do not drink water and they fast on the day of Ashora. What is more observed in the month of Moharram is giving food, i.e., lunch and dinner on the days of Tasua and Ashura in Jafaria Mosque and in some Ashorakhanas like Rashke Behesht. In other days as well, every family that wishes to give food sends it to mosque or gives its expenses so that food be given to the mourners in the mosque. Before supper, they serve tea, i.e., Indian tea made of tealeaves and milk and for supper, they usually have vegetarian food and after that, they serve mutton Biryani or chicken Biryani with bread and cucumber, etc. 


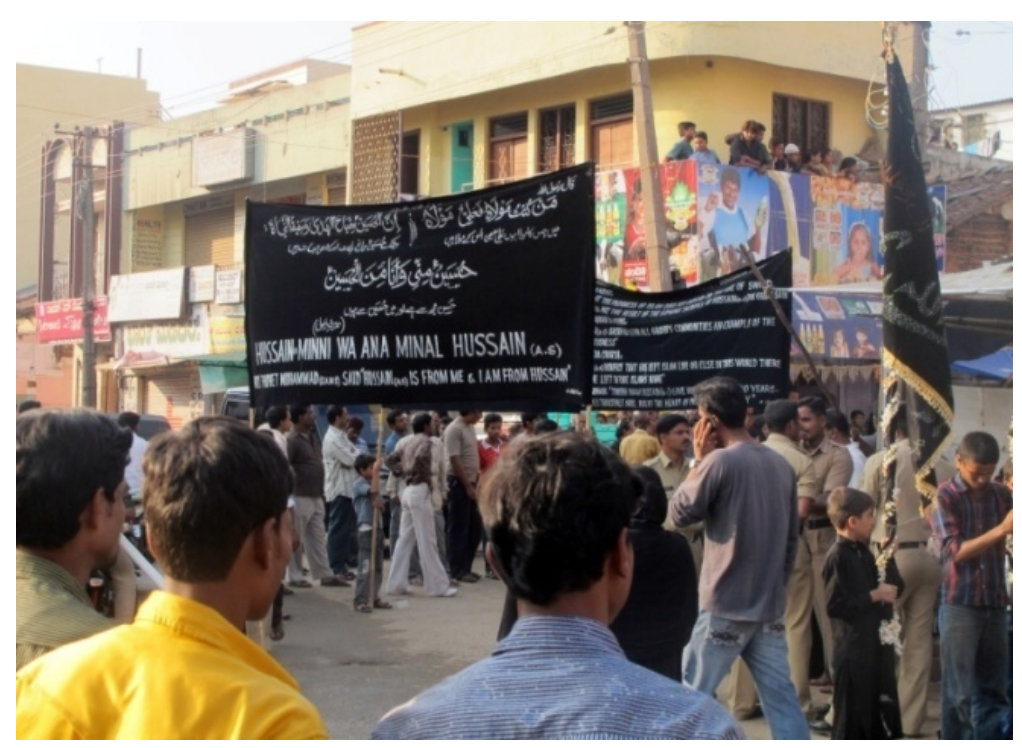

Figure 2. Moharram-Mysore

On the 7th day of Moharram, the stabbing ritual starts in one of the Ashorakhanas with mourning rituals. Young children, teenagers and old people start moving with sharp stabs and blades in their hands following a long flag (Alam) carried by one person in front of them. Kids in front and a horse, covered with white sheet that has red spots of symbolic blood and arrows on it, March in front of the crowd of mourners. The mourners, accompanied by a singer who tries to increase Husseini enthusiasm, stab themselves on the head, chest and back. Soon after, the smell of blood spreads all over the area. Before moving, I was among the mourners taking photos and picturing them. They gather in one Ashorakhana and sing elegies there; after that, the flag (Alam) and the horse with symbols of blood starts moving in the front. These symbols signify the memory of Karbala and the battle of Imam Hussein (PBUH) for the mourners. Also one person on another horse who carries a flag (Alam) decorated with jasmine flowers - as an Indian culture symbolizing Hazrat Ghasem-starts (a.s) moving with the group of mourners. Groups of children and youngsters as well as other mourners are observed in different circles in these rows. They cut themselves on the head and chest with knives, blades and daggers. This is one of the rituals that bring lots of people from different areas together. Of course, Mysore police tries to provide the ceremony with security. After that, they pass Mandi Mohalla Street and reach another Ashorakhana. They get entertained with tea and other drinks there. Women also in Ashorakhana perform their mourning by singing elegies. Moharram rituals in Mysore is one of the most outstanding religious ceremonies during which every night families give food to the mourners in Masjid Jafaria and the mourners eat dinner in the mosque. This food is called Tabarrok or offering for Imam Hussein (PBUH). On the day of Ashora, Shias of Mysore fast from morning till afternoon and eat nothing. This is called Fakhah. They even do not talk to anyone. They consider these rituals as parts of Moharram ceremony. Here, most Shias talk in Urdu and some others are fluent in English.

I started my interview with Mr. Mirza who is from Mysore and he works in one Ashorakhana and takes care of it. I visited Mirza Arjmand Ali who is Shia in Jafaria Mosque. He is 48, married, and has three children. He is an electrician and has diploma. He is from Mysore. He has a heritage from his family. Economically, he is self-sufficient. He says they hadn't had much religious tension in Mysore long back and people lived friendly lives together. But nowadays, this seems to be less; still we have peaceful lives together. We don't have much relationship with Christians in Mysore unless there is any dealing or business, etc. Religiously, Mysore is a good and secure place for Muslims. Wealth and education are considered as two important factors of social position here. However, it seems that those who have higher education are respected far more. As for migration, Shias of Mysore mostly go to Hyderabad and Bangalore, especially Bangalore which is closer to Mysore. It is better for both working and also for entertainment. As for abroad, most immigrants go to the Arab countries like Dubai, Saudi Arabia, etc. and fewer ones go to European countries like Australia, Canada, etc. But there are some other immigrants as well who come to Mysore from Bangalore, Hyderabad and Mumbai. Hindus and Sunnis compared to other minorities like Christians, Buddhists, etc. are the majorities in Mysore. Marriage rituals among Shias are almost like the ones among Hindus in which the whole expenses have to be paid by the girl's family; but if a boy wants to pay the expenditure, there is no problem with that. Still there is the system of solving problems with 
mediation of elderly people among Shias. They usually solve their problems themselves and hardly go to police to solve them legally; but for bigger problems, they get the help of police. In religious ceremonies, the managing board of Jafaria Mosque often collects some gifts and donations from people and spends it on Tabarrok food and on helping the poor; also if someone needs financial support for funeral ceremonies, etc. The board helps him. This helping is carried out in weddings and funerals. Leisure time for the people of Mysore is going to historical or entertainment places like Tipu Sultan, Mysore Palace, cinema, market, park, etc.

It seems that Mr. Mirza does not have any financial problem; in daytime, also he doesn't do anything special, unless it is needed. His brother has a hotel in Bangalore. The elder brother provides his own family and others by investing in Bangalore. Previously, Mirza's father was doing handicraft; but at the moment, Mirza himself has no hand in handicraft. He lives in Niagar Ashorakhana where his house is located. His brothers and sisters live in the Arabian countries. He also says that he loves Iran very much. He specially is very much interested in pilgrimage to Imam Reza's (PBUH) shrine, the eighth Imam of Shias in Iran. We must mention that most of the Shias in Mysore have special love for Imam Reza (PBUH) in Iran.

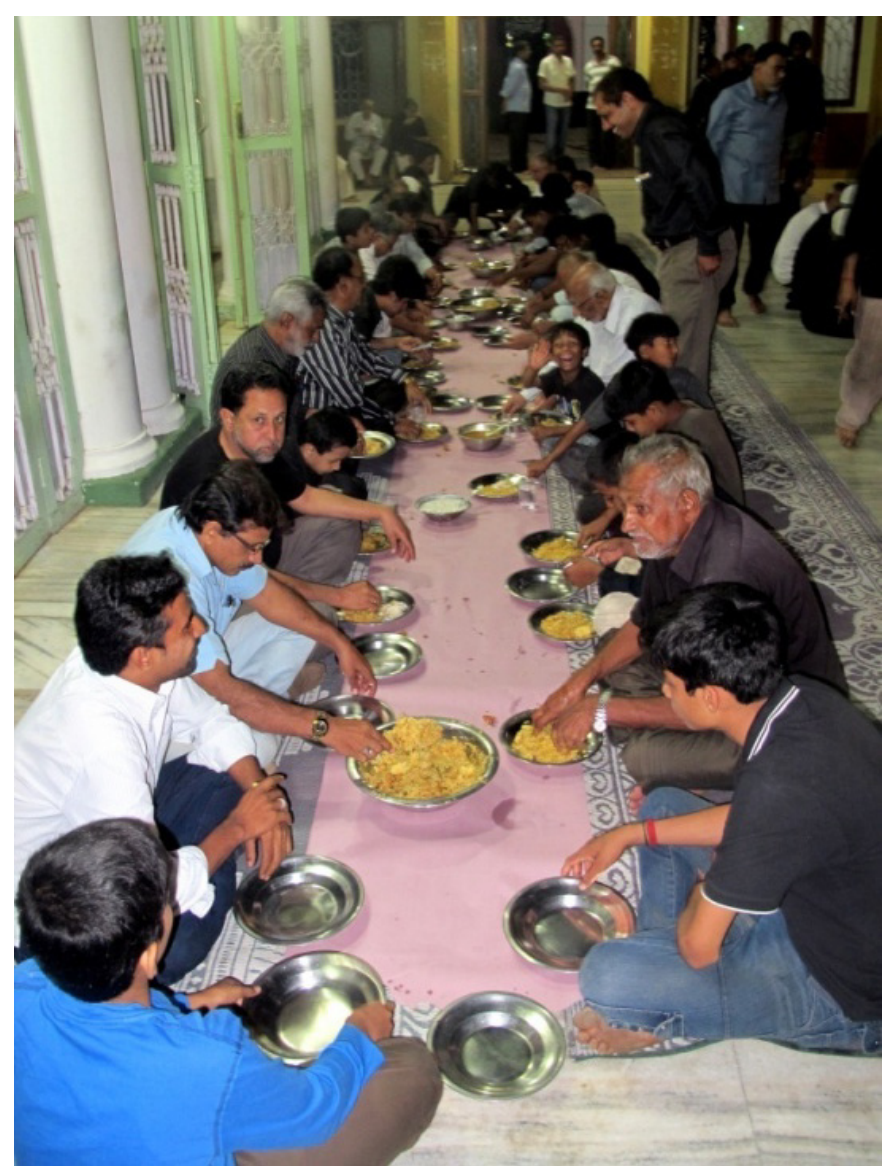

Figure 3. Tabarok food in Jafaria Mosque-Mysore 


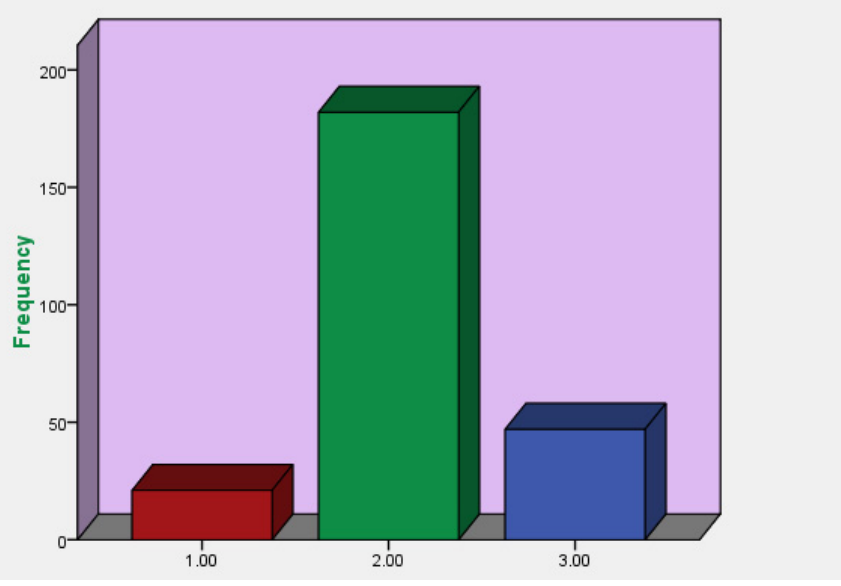

Figure 4. Level Status Shia Muslims in Mysore

In this figure, social and economic status of Shia Muslims in Mysore is demonstrated. In the first or low level, there are 21 members $8.4 \%$; in the second or medium level, there are 182 members $72.8 \%$; and in the third or high level, there are 47 members $18.8 \%$. Eventually, recognition of cultural identity and the influences of globalization on their economy are also remarkable aspects of these changes.

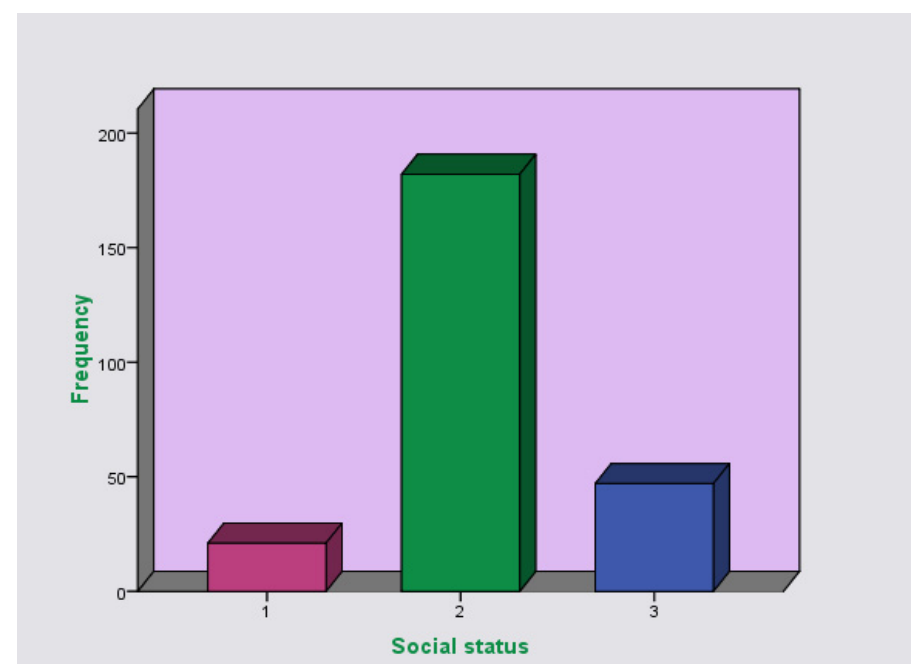

Figure 5. Social status

Social position also has been categorized. Level 1, i.e., low includes 15 members $6.0 \%$; level 2, i.e., medium has 167 members, i.e., $66.8 \%$ and level 3 or high includes 68 members $27.2 \%$. They are mentioned in the chart as well. Economy status shows 79 people, i.e., $31.6 \%$ in level $1 ; 143$ members $57.2 \%$ in level 2; and 28 people $11.2 \%$ in level 3 . 


\section{Conclusion}

The Shias religion of Isna Ashari flourished in Deccan in the 16th century AD. However, before that (approximately in 748-936/1347-1528), Bahmanid Kingdom was the first government, which prepared the basis for penetration of 12-Imamid Shiism in this region. Bahmanid rulers established independent kingdoms in Ahmad Nagar, Bijapur and Golkandeh, which resisted until the Mongol invasion. After spread of Imamia religion in the time of Shah Ismail Safavid in Iran, Bijapur was the first government to announce Shiism as its official religion in Deccan. This historical period also has been carefully studied in this research and of course the social as well as economic lives of Mysorean Shias population that is a very small scale of this great historical and cultural event in India.

At the beginning, Bahmani Sultans declared independence in the Northern Deccan; and after their decline, Deccan was divided between five governments that had great roles in continuation of spreading Iranian and Imami Shias culture till many decades after Bahmanis (Mosaheb, 2002). Barid Shahian Dynasty was established in central Deccan in the city of Bidar by Qasem Barid Turk. It was replaced by Adil shahi dynasty in $1629 \mathrm{AD}$ which was founded in Bijapur, in the northern border of Karnataka State by the Iranian Yusuf Khan Adil shahi. The importance of Adil shahi Dynasty is because of the introduction of Shiism to India in their period; another important point is the Iranian nationality of Adil shahis which originates from central Iran, Qum and Saveh. Their full dependence on Safavid dynasty is another important point about them (Basorth, 2002). Hollister has emphasized on their connection to Safavid court for spreading Iranian and Shias culture (Hollister, 1994).

In fact Yousuf introduced Shia Islam to India. He was from Iranian Shias; Iranians who were scholars, saints, literati and politicians took refuge in the different states of India. They laid the foundations for development of Iranian and Islamic culture with the support of Indian powers in the north and south of India, with their Persian language, which was the language of politics and literature. Formation of Islamic governments in the soil of India was equal to weakening of racial elements of Turkic, Indian and Mongol nations in the Iranian culture and civilization.

Islam entered India mostly through Iran; this means that people understood Islam in that country through Persian and they mostly converted to Islam through Iranian preachers, Sufis and scholars. Muslims of the Indian Subcontinent became familiar with Hadiths (sayings of the Prophet) and Tafseers (interpretations) of the Quran through their Persian translations. Commuting of the immigrants from Iran to and fro India brought more reciprocal cultural influences. Since the 10th century HG, in the Safavid period in Iran and Temurid period in India, these relationships have developed in all aspects; presence of Adilshahi Dynasty in Bijapur, which was part of Deccan, caused more immigration of Shias to that region especially because of this dynasty's close relations with Safavids in religion and beliefs. Adilshahis were very much concerned about buildings and turned their capital, Bijapur into one of the finest examples of Islamic architecture in India. They were supporters of arts and wisdom. Following that, the Shias thinkers and scholars enriched sciences and philosophy remarkably. Since the beginning of the Islamic history until the end of the 18th century, the Indian born Shias started developing the thought system of the country. As a result, the history of the thought system of Shias in India is the same history of the Iranian immigrants who brought a share of their best teachings from their country and introduced it to the society of cultures and arts in India. In addition to other reasons, development and spread of Shias Islam and Islamic Sufism is due to the efforts of scholars, Sufis, Iranian preachers as well as introduction of Persian books. Shias do not have independent political organization for themselves and the political Shias figures follow their political activities separately in all parties; hence, they are far behind Sikhs in this case. Unfortunately, the few Shia political figures in India do not have much concern for the improvement of the poor cultural and economic situation of Shias in this country. Shias are in very lower conditions compared to followers of other religions and sects. The considerable cultural and social organizations of Shias all over India are very few in numbers. Unfortunately, since the Shias in India consider themselves a minority, they have always been thinking about defending themselves and have rarely had the opportunity to spread the teachings of Ahle Bait. In order to defend themselves, they have sometimes made mistakes in knowing their enemies as well.

Status of Muslims state agencies should actively develop and implement policies geared to improving the socio-economic status of Shia Muslim women and the Muslim community generally to ensure their full participation in public life as Indian citizens. Such measures could include central government (collaboratively with state governments) implementation of loan schemes to facilitate the setting up of small businesses or skill training for Muslims; and the implementation of schemes for Muslim girls' and women's education in both rural and urban areas. This should be in conjunction with socio-economic measures so that Shia Muslim women, particularly in urban areas (where illiteracy levels are high), can enjoy such economic benefits. 


\section{Recommendations}

Status of Shia Muslims: given the poor educational and low socio-economic status of Shia Muslims in general, the central and state Governments should ensure the implementation of primary and secondary education programmers for Shia Muslims, particularly Shia Muslim women. A survey of availability of textbooks in minority languages should be undertaken, after which state governments should take up printing and distribution of textbooks.

The central and state governments must take measures to ensure the availability of teachers for Muslim communities, the appointment of women teachers, and the establishment of girls'/women's hostels with the provisions of mid-day meals and school uniforms. Schemes for adult literacy and reading rooms for Muslim communities must be undertaken by the central and state governments in order to address the compelling literacy needs of Shia Muslim women. In addition, state governments should institute scholarships for minority students. Removing social prejudice against Muslims: the central government must take appropriate action against people, institutions and political figures that practice or propagate discrimination or intolerance based on religion.

\section{References}

Ahmad, I. (1973). Caste and Social Stratification among Muslims in India. New Delhi.

Ahmad, I. (1981). Ritual and Religion among Muslims in India. New Delhi, 12(4), 23.

Ahmad, I. (2008). Cracks in the "Mightiest Fortress", Jamaat-e-Islami's Changing Discourses on Women. In Modern Asian Studies (pp. 549-575). http://dx.doi.org/10.1017/S0026749X07003101

Basorth, K. E. (2002). New Islamic Dynasties. In Handbook of Chronology and Genealogy (p. 613). Tehran: Baz Press.

Chatterji, R. (1998). The Bengali Muslim: A Contradiction in Terms? In An Overview of the Debate on Bengali Muslim Identity, in Mushirul Hassan, Islam, Communities and the Nation. New Delhi: Manohar Publications.

Dale, S. (1980). Islamic Society on the South Asian Frontier, the Mappilas of Malabar 1498-1922. New York, Oxford University Press.

Dale, S. (1988). Religious Suicide in Islamic Asia, Anti-Colonial Terrorism in India, Indonesia and Philippines. The Journal of Conflict Resolution, 32(1), 37-59. http://dx.doi.org/10.1177/0022002788032001002

Dale, S. (1991). Conversion to Islam in Kerala, in Oddie G A. In Religion in South Asia. New Delhi: Manohar Publications.

El Zeinh, A. H. (1977). Beyond Ideology and Theology. The Search for Anthropology of Islam: Annual Review of Anthropology, 6, 227-228. http://dx.doi.org/10.1146/annurev.an.06.100177.001303

Filppo, O., \& Caroline, O. (2007). Muslims Entrepreneurs between India \& the Gulf ISIM Review (Vol. 19, pp. $8-9)$.

Filppo, O., \& Caroline, O. (2008b). Islamic and Social Reform in Kerala, South India. Modern Asian Studies, $42(2 / 3), 317-346$.

Gadgil, \& Guha. (1992). Society and Islam in South Asia. New York: Oxford University Press.

Guha, R. (1982). On Some Aspects of the Historiography of Colonial India. In Writings on South Asian History and Culture (pp. 1-8). Delhi, Oxford.

Hefner, R. (1998). Multiple Modernities, Christianity, Islam and Hinduism in a Globalizing Age. Annual Review of Anthropology, 27, 83-104. http://dx.doi.org/10.1146/annurev.anthro.27.1.83

Hollister, J. N. (1994). Shiism in India. Tehran: Nashre Daneshgahi Press.

Madan, T. N. (2007). One from Many: Explorations in the Anthropology of Islam. Eastern Anthropologist, 60(1), $1-26$.

Mayaram, S. (1998). Rethinking Meo Identity: Cultural Fault line, Syncreticism. In H. Mushirul (Ed.), Communities and the Nation. New Delhi: Manohar Publications.

Mines, M. (1975). Islamisation and Muslims Ethnicity in South India. Man, New Series, 10(3), 404-419. http://dx.doi.org/10.2307/2799810

Moaddel, M. (1998). Religion and Women: Islamic Modernism versus Fundamentalism. Journal for the Scientific Study of Religion, 37(1), 108-130. http://dx.doi.org/10.2307/1388032 
Mosaheb, G. H. (2002). Persian Encyclopedia (p. 885). Tehran: Amir Kabir Press.

Mutahhari, M. (1983). Reciprocal Services of Islam and Iran. Tehran:Sadra Press.

\section{Copyrights}

Copyright for this article is retained by the author(s), with first publication rights granted to the journal.

This is an open-access article distributed under the terms and conditions of the Creative Commons Attribution license (http://creativecommons.org/licenses/by/4.0/). 